\title{
A theoretical model for predicting the behaviour of BTEX in the unsaturated zone and groundwater (Bahía Blanca, Argentina).
}

Victoria Zanello ( $\square$ victoria.zanello@uns.edu.ar)

Universidad Nacional del Sur https://orcid.org/0000-0001-8889-1925

Leonardo Ezequiel Scherger

Universidad Nacional del Sur

Micaela Carbajo Castoldi

Universidad Nacional del Sur

Claudio Lexow

Universidad Nacional del Sur

\section{Research Article}

Keywords: Mathematical model, BTEX, risk of contamination, unsaturated zone, groundwater, Bahía Blanca

Posted Date: March 31st, 2021

DOl: https://doi.org/10.21203/rs.3.rs-325170/v1

License: (c) (i) This work is licensed under a Creative Commons Attribution 4.0 International License. Read Full License 


\title{
A theoretical model for predicting the behaviour of BTEX in the unsaturated zone and groundwater (Bahía Blanca, Argentina).
}

\author{
Victoria Zanello ${ }^{1,2 *}$; Leonardo E. Scherger ${ }^{1,2}$; Micaela Carbajo Castoldi ${ }^{1}$; Claudio Lexow ${ }^{2,3}$ \\ ${ }^{1}$ CONICET, CCT Bahía Blanca. Camino La Carrindanga, Bahía Blanca, Argentina. \\ 2 Dpto. de Geología, Universidad Nacional del Sur (UNS), Bahía Blanca, Argentina. \\ ${ }^{3}$ Centro de Geología Aplicada, Agua y Medio Ambiente (CGAMA-CIC-UNS). Comisión de Investigaciones Científicas, Bahía Blanca, Argentina.
}

* Correspondence to: Victoria Zanello, Tel.: +54 (0291) 459-5000 Int.: 3051.

E-mail: victoria.zanello@uns.edu.ar

Declarations

Ethics approval and consent to participate: Not applicable

Consent for publication: Not applicable

Availability of data and materials: All data generated or analysed during this study are included in this published article.

Competing interests: The authors declare that they have no competing interests.

Funding: This work was financially supported by the Universidad Nacional del Sur (UNS), Comisión de Investigaciones Científicas (CIC) and Consejo de Investigaciones Científicas y Técnicas (CONICET).

Authors' contributions: V.Z., L.E.S. and C.L. contributed to the study conception and design. Material preparation, data collection and analysis were performed by V.Z., L.E.S. and C.L. The first draft of the manuscript was written by V.Z. and L.E.S. Figures were made and edited by M.C.C. All authors commented on previous versions of the manuscript. All authors read and approved the final manuscript.

ACKNOWLEDGEMENTS: The authors want to acknowledgement the institutions that support the work: Universidad Nacional del Sur, CONICET y CIC. 


\begin{abstract}
Gas stations are one of the most important sources of soil and groundwater contamination in urban areas around the world. In this work, a mathematical model was applied to assess the risk of the physical media contamination. The model is based on the chemical properties of fuels and site-specific hydrological properties. The group of hydrocarbons selected were the monoaromatic: benzene, toluene, ethylbenzene and xylene (BTEX). The mathematical model was used to evaluate the behaviour of each compound in each partitioning phase (dissolved, volatile, solid and non-aqueous liquid phase). Furthermore, mass flux of BTEX reaching groundwater was calculated according to steady flow under two different conditions: (1) considering only sorption and volatilization, and (2) adding biodegradation. In all cases, the total mass of BTEX leachate was greater when biodegradation was not considered. In areas with unsaturated zone thickness greater than two meters, sorption is the main process affecting BTEX transport. Otherwise, when water table is placed at shallower depths, contaminants are predominately dissolved. In all cases, the lowest proportion of BTEX were in the volatile phase. The model presented in this work proved to be an interesting tool to evaluate the behaviour of BTEX in soil and groundwater and its applicability being directly related to environmental and urban management of pollution from gas stations. The methodology applied in this work could be extrapolated to any site of the world with the same problematic. Particularly, the theoretical model allowed to defined zones with high and low risk of contamination in Bahia Blanca, Argentina.
\end{abstract}

Keywords: Mathematical model; BTEX; risk of contamination; unsaturated zone; groundwater; Bahía Blanca

\title{
INTRODUCTION
}

Over the years, the most common form of gasoline contamination is leakages from underground hydrocarbon storage system (UHSS), mainly located in gas stations (Fetter 1999). For this reason, in urban areas, gas stations are one of the main sources of contamination of the unsaturated zone (UZ) and groundwater (Silva 2005).

The presence of hydrocarbons in the subsoil represents an important threat to the environment. Petroleum hydrocarbon spills may cause significant deterioration of groundwater quality due to the presence of highly toxic components such as benzene, toluene, ethylbenzene, and xylene (BTEX). This group of monoaromatic compounds is important because they have the highest solubility and mobility among petroleum hydrocarbons (Derrick et al. 2005). Furthermore, BTEX have innate partitioning capabilities that allow its components reach various compartments in the subsoil. Consequently, investigating the fate and transport of BTEX is essential to reduce the adverse effects of oil leaks (Valsala and Govindarajan 2018).

Selection of an appropriate mathematical model is essential to predict the behaviour and fate of hydrocarbon contaminants. As a result, an appropriate model for water flow in unsaturated soils must include physical mechanisms of water flow, and consider heterogeneity in the structure and formation of soils. Therefore, simulation of water flow and hydraulic phenomena in soil is a complex problem due to the complex and heterogeneous nature of soils and participation numerous factors involved.

There are several works carried out in the last 20 years investigating the migration of BTEX spilled into the underground environment (Park and Juan 2000; Thomas and Tellam 2004; Atteia and Guillot 2007; Valsala and Govindarajan 2018; RodrigoIllari et al. 2018; Zanello et al. 2021, among others). Park and Juan (2000) used a theory-based computer software (GW plot) to calculate soil cleanliness levels that protect groundwater at complex NAPL-contaminated sites. Thomas and Tellam (2004) assess groundwater contamination risk from gas stations in England from a mathematical model considering sorption, dissolution and biodegradation. Valsala and Govindarajan (2018) presented a mathematical model that contemplates that BTEX undergoes the same processes as considered by Tomas and Tellam (2004) but in the saturated zone. The spatial and temporal concentration of these compounds is calculated considering that they are dissolved in groundwater. In turn, Rodrigo-Ilarri et al. (2018) quantified the concentrations of BTEX in the UZ, by means of a one-dimensional mathematical model that is solved through the application of VLEACH. Zanello et al. (2021) studied the risk of groundwater contamination related to residual fuel phase in the study area, using HYDRUS 2D/3D.

In this work, a mathematical model was evaluated as a tool to assess the risk of contamination of the physical environment (soil and groundwater). The model combines the chemical properties of petroleum fuels and the specific hydrologic properties of the sites. The main objective of this study is to verify the potentiality of using a low-cost and quick-results tool to predict the behaviour of BTEX in the subsoil and groundwater after a petrol leak. On the one hand, it will allow us to protect susceptibility aquifers to being contaminated by future installations. On the other hand, if the contamination is already present, it will allow us to design a remediation plan according to the situation of each site.

\section{Study area}

Bahía Blanca is located in the Southwest sector of the Buenos Aires Province, Argentina, between $38^{\circ} 39^{\prime}$ and $38^{\circ} 48^{\prime}$ S latitudes and $62^{\circ} 21^{\prime}$ and $62^{\circ} 10^{\prime} \mathrm{W}$ longitudes. In 1990, a census done in Bahía Blanca informed that $90 \%$ of gas stations had leaks from their UHSS and pipes (Lexow 1994). Nowadays, there are 40 registered gas stations (active and inactive) on a $2.247 \mathrm{~km}^{2}$ surface. The subsoil is characterized by variations in its sedimentological properties. Hence, each sector of the city presents a different hydrodynamic behaviour. According to the city geomorphology, the water table is located at fluctuating depths between 2 and 
30 meters (Caló et al. 1999). Due to these conditions, this case study is a good example to evaluate the effectiveness of the theoretical model.

Different geomorphological units in Bahía Blanca city are shown in Fig. 1. The central area is located over an alluvial fan, between 10 and 30 m.a.s.l. In the northeast, there is a plateu whose elevation slightly exceeds 80 m.a.s.l. and which descends moderately to the west and south to heights no greater than 60 m.a.s.1.. The edge of this plain is continued by a slope, included between 10 and 60-80 m.a.s.l. elevations, which constitutes a colluvial-alluvial complex and coalescent alluvial cones. In the south, the coastal area extends between 0 and 10 m.a.s.l. altitudes corresponding to an emerged old tidal plain (Caló et al. 1999). The aquifer recharge zones are located in the highest topographic region while discharge zones are next to the coast. The main groundwater flow direction is NW-SE (Caló et al. 1999). Despite its saline to hypersaline characteristics (Bonorino and Sala 1983), the phreatic aquifer is usually used for irrigation and recreation proposes.

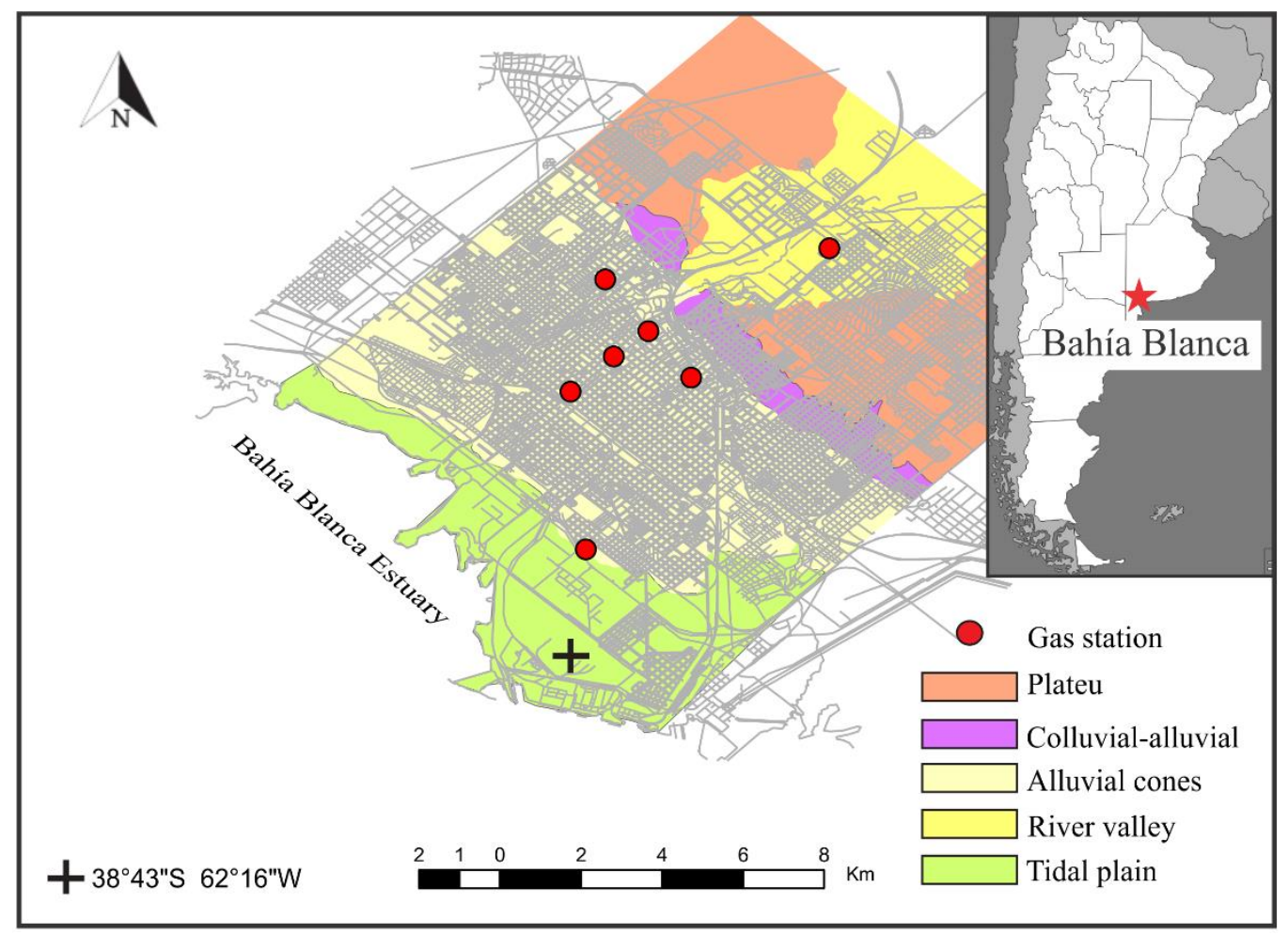

Fig. 1 Map of the geomorphologic units of Bahía Blanca city (Modify from Pérez Marfil et al. 2019)

\section{THEORETICAL FRAMEWORK}

\section{Behaviour and properties of petroleum hydrocarbons in the ground}

Leaks produced over the years from UHSS and associated pipes generate a gradual accumulation of hydrocarbons in the UZ. When the quantity of petroleum fuel is enough, gravity and capillary forces cause the movement of fuel. Part of the hydrocarbon is retained in pores and fractures of soil as a residual phase. Another part, depending on Henry's constant, can also volatilize. The mobile non-aqueous liquid phase (NALP) will continue to migrate until it reaches the capillary fringe. In this place, competition with water begins. NALP is a non-humidifying phase that is less dense than water, therefore, a plume is generated. NALP floats above the water table and moves laterally depending on the hydraulic gradient. Dissolution of chemical compounds occurs in contact between petroleum fuel and groundwater (Kim and Corapcioglu 2003).

Mobility and transport of NALP is controlled by different parameters. These parameters include: properties of liquid phase (density, viscosity, solubility, vapor pressure, volatility and interfacial tension), characteristics of soil in which it is propagated (capillary force or pressure head, pore size distribution, initial moisture content, strata geological structure, and groundwater velocity) and saturation functions (residual saturation and relative permeability) (Celis 2009).

The fuels are a mixture of a large quantity of hydrocarbons. There are typical hydrocarbons that are used as indicators of their presence. In particular, those who may represent a risk to people are considered. The most used are aromatic hydrocarbons, mono and polynuclear, that are toxic and several of them have been shown to be carcinogenic (WHO 1989). Furthermore, BTEX components are the most soluble and mobile fraction of fuel hydrocarbon, and as such, frequently enter soil, sediments and aquatic environments (Njobuenwu et al. 2008). 
Leakages of UHSS or pipes correspond to gasoline or diesel. Percentages of BTEX compound vary according to the predominant petroleum hydrocarbon. Weight percentage of each compound according to oil type is listed on Table 1. So, the compounds have specific chemical and partitioning properties. The properties considered at $20^{\circ} \mathrm{C}$ are listed in Table 2 , taken from Thomas and Tellam (2004).

Table 1 Percentage of BTEX in petroleum fuel. Taken from Gustafson et al. 1997

\begin{tabular}{|c|c|c|c|}
\hline BTEX & Carbon number & Weight percent in gasoline & Weight percent in diesel \\
\hline Benzene & 6 & $0.12-3.5$ & $0.003-0.10$ \\
\hline Toluene & 7 & $2.73-21.8$ & $0.007-0.70$ \\
\hline Ethylbenzene & 8 & $0.36-2.86$ & $0.007-0.20$ \\
\hline o-Xylene & 8 & $0.68-2.86$ & $0.001-0.085$ \\
\hline m-Xylene & 8 & $1.77-3.87$ & $0.018-0.512$ \\
\hline p-Xylene & 8 & $0.77-1.58$ & $0.018-0.512$ \\
\hline
\end{tabular}

Table 2 Specific chemical properties and partitioning coefficients of BTEX

\begin{tabular}{|c|c|c|c|c|c|c|c|}
\hline BTEX & $\begin{array}{c}\text { Weight } \\
\text { percentage } \\
\text { in oil }(\%)\end{array}$ & $\begin{array}{c}\text { Molecular } \\
\text { weight (g/mol) }\end{array}$ & $\begin{array}{c}\text { Water } \\
\text { solubility } \\
(\mathbf{m g} / \mathrm{L})\end{array}$ & $\begin{array}{c}\text { Vapor } \\
\text { pressure at } \\
25^{\circ} \mathrm{C} \text { (atm) }\end{array}$ & $\begin{array}{c}\text { Henry's } \\
\text { constant } \\
\text { (atm- } \\
\left.\text { m³ }^{3} / \mathbf{m o l}\right)\end{array}$ & $\begin{array}{c}\mathbf{K}_{\mathrm{oc}} \\
(\mathrm{L} / \mathrm{kg})\end{array}$ & $\begin{array}{l}\text { Half- } \\
\text { life } \\
\text { T(1/2) } \\
\text { days }\end{array}$ \\
\hline Benzene & 1.9 & 78.11 & 1780 & 0.125 & $5.59 \mathrm{E}-03$ & 83 & 720 \\
\hline Toluene & 8.1 & 92.14 & 515 & 0.037 & $6.37 \mathrm{E}-03$ & 30 & 28 \\
\hline Ethylbenzene & 1.7 & 106.17 & 152 & 0.013 & $6.43 \mathrm{E}-03$ & 1100 & 228 \\
\hline Xylene & 9 & 106.17 & 175 & 0.012 & $5.10 \mathrm{E}-03$ & 830 & 360 \\
\hline
\end{tabular}

\section{BTEX partition and solute transport in vadose zone}

Contaminants partition in soil-water, air-water or NALP-water interfaces depend on chemical properties and solubility of each compound (Cipullo et al. 2018). BTEX transport in soil media can be described based on mathematical equations (mathematical model by Thomas and Tellam 2004). Distribution and partition of BTEX during their transport in UZ can be modelled by the following steps.

Once leak is generated, phases present in soil pores are water, air and hydrocarbon. The partition percentage of each phase can be expressed according to the porosity occupied. Thus, soil total porosity (n) in UZ is composed of:

$$
\mathrm{n}=\theta_{\mathrm{w}}+\theta_{\mathrm{a}}+\theta_{\mathrm{NALP}}
$$

where $\theta_{w}$ is volumetric water content $\left(\mathrm{cm}^{3} / \mathrm{cm}^{3}\right) ; \theta_{a}$ is volumetric air content $\left(\mathrm{cm}^{3} / \mathrm{cm}^{3}\right) ; \theta_{N A P L}$ is volumetric NAPL content $\left(\mathrm{cm}^{3} / \mathrm{cm}^{3}\right)$.

According to Clapp and Hornberger method (Clapp and Hornberger, 1978) average volumetric water content in UZ $\left(\theta_{w}\right)$ can be calculated as:

$$
\theta_{\mathrm{w}}=\theta_{\mathrm{s}} *\left(\frac{\mathrm{V}_{\mathrm{d}}}{\mathrm{K}_{\mathrm{S}}}\right)^{\frac{1}{2 \mathrm{~b}+3}}
$$

where $\theta_{s}$ is saturated water content of the soil (total porosity); $V_{d}$ is recharge rate $(\mathrm{m} / \mathrm{d})$ and $K_{s}$ is saturated hydraulic conductivity $(\mathrm{m} / \mathrm{d})$. Constant $\mathrm{b}$ is an empirical parameter whose value depends directly on soil texture. It could vary from 4.5 for a sandy soil to 11 for a clayed soil.

When a petroleum fuel leak occurs, certain pores will become occupied by hydrocarbon. Assuming that Clapp and Hornberger method is valid when NAPL is present, volumetric water content in UZ can be estimated and, volumetric air content $\left(\theta_{a}\right)$ would be:

$$
\theta_{\mathrm{a}}=\mathrm{n} *\left(\theta_{\mathrm{NAPL}}+\theta_{\mathrm{w}}\right)
$$

Condition: $\mathrm{n}>\left(\theta_{\mathrm{NAPL}}+\theta_{\mathrm{W}}\right)$ and $\mathrm{UZ}$ depth $>0$. When saturated air content in profile soil is zero.

Volumetric NAPL $\left(\theta_{\mathrm{NAPL}}\right)$ content in UZ can be estimated as:

$$
\theta_{\mathrm{NAPL}}=\frac{\mathrm{n}^{*} \theta_{\mathrm{rNAPL}}}{100}
$$


Measuring residual saturation $\left(\theta_{r_{N A P L}}\right)$ in field is complex. Some laboratory studies (Mercer and Cohen 1990) indicated that it could vary from $10 \%$ to $20 \%$ depending on the type of product. In this work $10 \%$ of total porosity was considered. Under these considerations, total mass of each compound (m), expressed by soil volume, can be calculated from:

$$
\mathrm{m}=\theta_{\mathrm{w}} * \mathrm{C}_{\mathrm{w}}+\theta_{\mathrm{a}} * \mathrm{C}_{\mathrm{a}}+\theta_{\mathrm{NAPL}} * \mathrm{C}_{\mathrm{NAPL}}+\delta_{\mathrm{a}} * \mathrm{C}_{\mathrm{s}}
$$

where $\delta_{a}$ is the bulk density of the soil.

Eq. (5) also requires definition of concentration of each compound in each phase present in UZ: water $\left(C_{w}\right)$, air $\left(C_{a}\right)$, NAPL $\left(\mathrm{C}_{\mathrm{NAPL}}\right)$ and solid $\left(\mathrm{C}_{\mathrm{s}}\right)$ phases. Distribution of each solute is defined by partition coefficients: soil-water $\left(\mathrm{K}_{\mathrm{d}}\right)$, water-air $\left(\mathrm{K}_{\mathrm{h}}\right)$ and water-NAPL $\left(\mathrm{K}_{0}\right)$ respectively.

The soil-water partitioning coefficient $\left(K_{d}\right)$ is estimated using the following relationship:

$$
\mathrm{K}_{\mathrm{d}}=\mathrm{K}_{\mathrm{oc}} * \mathrm{~F}_{\mathrm{oc}}
$$

where $K_{o c}$ is organic carbon partitioning coefficient and $F_{o c}$ is organic carbon fraction.

Volatilization process can be explained by applying of Henry's Law, water-air partitioning coefficient $\left(K_{h}\right)$ is represented by:

$$
\mathrm{K}_{\mathrm{h}}=\frac{\mathrm{K}_{\mathrm{h}}^{\prime}}{\mathrm{R}^{*} \mathrm{~T}}
$$

where $\mathrm{K}_{\mathrm{h}}$ is Henry's constant for BTEX compound (atm- $\left.\mathrm{m}^{3} / \mathrm{mol}\right)$; $\mathrm{R}$ is the universal gas constant $\left(\mathrm{atm}-\mathrm{m}^{3} / \mathrm{mol}-\mathrm{K}\right)$ and $\mathrm{T}$ is temperature $\left({ }^{\circ} \mathrm{K}\right)$.

Raoult's law is valid according to Cline et al. (1991) if we assume that: (1) the source in study is dissolving in equilibrium, (2) an ideal behaviour of the components and (3) a large area of contact between residual NAPL and groundwater. This law can be used to define water-NAPL partition coefficient $\left(K_{o}\right)$ given the concentration of different constituents in NAPL (Feenstra et al. 1991). Even if the constituents of NAPL change over time due to occurrence of processes such as dissolution, volatilization, degradation and sorption, value of $K_{o}$ is presumed constant for calculation of this model.

$$
\mathrm{K}_{\mathrm{o}}=\frac{\text { average } \mathrm{MW} \text { of compound*average MW of NALP }}{\mathrm{S}_{\text {effective }}}
$$

The effective solubility ( $S_{\text {effective }}$ ) of an organic substance in a mixture is calculated using Raoult's law (Feenstra et al. 1991). The effective solubility is estimated multiplying molar fraction of the compound in the mixture by solubility of pure substance (S).

$$
\mathrm{S}_{\text {effective }}=\frac{\% \text { by weight of NAPL compound*average MW of NAPL*S }}{\text { average MW of compound*100 }}
$$

where MW is molecular weight.

The amount of each compound shall be distributed in different phases present in soil: dissolved phase, volatile phase, solid phase and liquid phase. The terms of Eq. (5) can be estimated as follows:

$$
\begin{aligned}
& \mathrm{C}_{\mathrm{w}}=100 *\left(\frac{\theta_{\mathrm{w}}}{\mathrm{B}_{\mathrm{w}}}\right) \\
& \mathrm{C}_{\mathrm{a}}=100 *\left(\frac{\theta_{\mathrm{a}} \mathrm{K}_{\mathrm{h}}}{\mathrm{B}_{\mathrm{w}}}\right) \\
& \mathrm{C}_{\mathrm{s}}=100 *\left(\frac{\delta_{\mathrm{a}} \mathrm{K}_{\mathrm{d}}}{\mathrm{Bw}}\right) \\
& \mathrm{C}_{\mathrm{NAPL}}=100 *\left(\frac{\theta_{\mathrm{NAPL}}{ }^{*} \mathrm{~K}_{\mathrm{o}}}{\mathrm{B}_{\mathrm{w}}}\right)
\end{aligned}
$$

Parameter $B_{w}$ is bulk water partitioning coefficient (1/gr), defined as:

$$
\mathrm{B}_{\mathrm{w}}=\theta_{\mathrm{w}}+\left(\theta_{\mathrm{a}} * \mathrm{~K}_{\mathrm{h}}\right)+\left(\theta_{\mathrm{NAPL}} * \mathrm{~K}_{\mathrm{o}}\right)+\left(\delta_{\mathrm{a}} * \mathrm{~K}_{\mathrm{d}}\right)
$$

Once the leakage occurs, petroleum fuels concentrations in the pore system volume $\left(\mathrm{M}_{\mathrm{i}}\right)$ can be calculated according to Eq. (15) for each BTEX. It is required: average density $\left(\delta_{\text {fuel }}\right)$ between oil and diesel $\left(765 \mathrm{~kg} / \mathrm{m}^{3}\right)$, total soil porosity $(\mathrm{n})$ and molar fraction of each compound $\left(F M_{i}\right)$.

$$
\mathrm{M}_{\mathrm{i}}=\mathrm{n} * \delta_{\text {fuel }} * \mathrm{FM}_{\mathrm{i}}
$$

When analysing solute transport in a multiphase system, it is common to express concentrations in each phase relative to a reference phase. Charbeneau and Daniel (1992) considered it advisable to take water phase $\left(d_{w}\right)$ as a reference phase to analyse leaching of contaminant. Therefore: 


$$
\mathrm{d}_{\mathrm{w}}=\frac{M_{i}}{\mathrm{~B}_{\mathrm{w}}}
$$

Thus, an estimation of the concentration of dissolved BTEX $\left(\mathrm{C}_{\mathrm{i}}\right)$ in poral water can be calculated from the following relationship:

$$
\mathrm{C}_{\mathrm{i}}=\frac{\mathrm{V} * \theta_{\mathrm{w}} * \mathrm{~d}_{\mathrm{w}}}{\theta_{\mathrm{NAPL}}}
$$

where $\mathrm{V}$ is the volume of petroleum fuel leakage.

As a result, the initial contaminant mass flux (Fi) present in the leaching per unit area is estimated by combining Eq. (17) with convective transport equation for unsaturated media:

$$
\mathrm{F}_{\mathrm{i}}=\mathrm{C}_{\mathrm{i}} * \frac{\mathrm{V}_{\mathrm{d}}}{\theta_{\mathrm{w}}}
$$

Based on steady state flow in the UZ, two scenarios for solute transport could be modelled:

1. Considering processes of sorption and volatilization;

2. Considering processes of sorption, volatilization and biodegradation.

In the first case, final concentration of compounds in recharge could be accepted as equal to initial concentration of leachate. Adsorption and volatilization processes are represented by a retardation factor $\left(\mathrm{R}_{\mathrm{f}}\right)$.

$$
R_{f}=1+\frac{\delta_{\mathrm{a}} * \mathrm{~K}_{\mathrm{d}}+\left(\theta_{\mathrm{s}}-\theta_{\mathrm{w}}\right) * \mathrm{~K}_{\mathrm{h}}}{\theta_{\mathrm{w}}}
$$

Consequently, transit time ( $\mathrm{T}$ ) of a given solute, without considering dispersion, can be calculated as:

where $\mathrm{z}$ is the depth of UZ.

$$
\mathrm{T}=\frac{\mathrm{z}^{*} \theta_{\mathrm{w}}{ }^{*} R_{f}}{\mathrm{~V}_{\mathrm{d}}}
$$

Finally, contaminant velocity is:

$$
\mathrm{V}_{\mathrm{c}=} \frac{\mathrm{V}_{\mathrm{d}}}{\theta_{\mathrm{w}}{ }^{*} R_{f}}
$$

Considering contaminant velocity $\left(\mathrm{V}_{\mathrm{c}}\right)($ Eq. 21) and BTEX concentration in poral water (Eq. 17), mass flux per unit of time and space is obtained as:

$$
\mathrm{F}=\mathrm{V}_{\mathrm{c}} * \mathrm{C}_{\mathrm{i}}
$$

In the second case, biodegradation is incorporated into processes described above. In aerobic environments, biodegradation of petroleum fuels can be explained mathematically according to a first-order decay model as:

$$
\mathrm{C}_{2}=\mathrm{C}_{i} * \mathrm{e}^{\mathrm{T} \lambda}
$$

where $\mathrm{C}_{2}$ is concentration of contaminant in $\mathrm{UZ}$ and $\lambda$ is the first order degradation coefficient $\left(\mathrm{t}^{-1}\right)$.

Combining the expression above (Eq. 23) with the expression of transit time (Eq. 20), in terms of half-life ( $\mathrm{t}_{1 / 2}$ ) for each compound, $\mathrm{C}_{2}$ can be expressed as:

$$
\mathrm{C}_{2}=\mathrm{C}_{\mathrm{i}} \operatorname{EXP}\left(\frac{-0.693 * R_{f} * \mathrm{Z} * \theta_{\mathrm{w}}}{\mathrm{V}_{\mathrm{d}} * \mathrm{t}_{1 / 2}}\right)
$$

To calculate final concentration of leachate reaching water table (F) is used Eq. (24). Hence, mass flux per unit area considering biodegradation is equal to:

$$
\mathrm{F}=\mathrm{V}_{c} * \mathrm{C}_{2}
$$

\section{METHODOLOGY}

Background data of seven gas stations located in Bahía Blanca were used to run the model (Fig.1). Main hydrogeological characteristic of each site is presented in table 3 . 
Table 3 Physical properties of gas stations

\begin{tabular}{|c|c|c|c|c|c|c|c|}
\hline $\begin{array}{c}\text { Gas } \\
\text { stations }\end{array}$ & Texture & $\begin{array}{c}\text { Water } \\
\text { table } \\
\mathbf{d e p t h}(\mathbf{m})\end{array}$ & $\begin{array}{c}\text { Total } \\
\text { porosity } \% \\
(\mathbf{1})\end{array}$ & $\begin{array}{c}\text { Effective } \\
\text { porosity } \% \\
\mathbf{( 1 )}\end{array}$ & $\begin{array}{c}\text { Bulk } \\
\mathbf{d e n s i t y} \\
\left(\mathbf{g} / \mathbf{c m}^{\mathbf{3}}\right)\end{array}$ & $\begin{array}{c}\text { Permeability } \\
(\mathbf{m} / \mathbf{d})\end{array}$ & $\begin{array}{c}\text { Constant } \\
\mathbf{b}^{(\mathbf{2})}\end{array}$ \\
\hline $\mathrm{A}$ & Clay loam & 1.5 & 40 & 10 & 1.59 & 0.086 & 8.52 \\
\hline $\mathrm{B}$ & Sandy loam & 3.4 & 30 & 15 & 1.86 & 0.864 & 4.90 \\
\hline C & $\begin{array}{c}\text { Clay loam with } \\
\text { calcareous cement }\end{array}$ & 1.8 & 25 & 5 & 1.99 & 0.090 & 8.52 \\
\hline D & Sandy clay loam & 2 & 40 & 12 & 1.59 & 0.864 & 7.12 \\
\hline E & Sandy loam & 2.7 & 30 & 15 & 1.86 & 0.864 & 4.90 \\
\hline F & Sandy clay loam & 2.1 & 40 & 12 & 1.59 & 0.864 & 7.12 \\
\hline G & Loamy sand & 3.5 & 35 & 15 & 1.72 & 0.864 & 4.38 \\
\hline
\end{tabular}

(1)Sanders (1998) (2)Freeze and Cherry (1979) (3)Clapp and Hornberger (1978)

Historical rainfall in the city was estimated as $555 \mathrm{~mm}$ (Caló et al. 2004). Recharge rate was considered as $11 \%$ of historical rainfall (Carrica and Lexow 2006) for gas stations located in the tidal plain (sites A) without water-proof surface. For the rest of the gas stations, the recharge rate was considered as $7 \%$ of rainfall.

Depth of water table was conservatively considered at the lowest value recorded. UHSS were located two meters below the surface for sites B, E and G, and at 1.40 meters below the surface for sites A, C, D and F. Volume of petroleum fuel leaked was calculated according to the number of underground tanks installed in each site and its capacity. In the city, each gas station has between four to six UHSS, with store capacity from 100000 to 120000 litres of petroleum fuel. Information available is listed in Table 4. For this study, it was considered a thickness of one meter for UHSS and an affected area of 25 litres per square meter.

Table 4 Information for UHSS at gas stations

\begin{tabular}{|c|c|c|c|}
\hline $\begin{array}{c}\text { Gas } \\
\text { stations }\end{array}$ & $\begin{array}{c}\mathbf{N}^{\circ} \text { installed } \\
\text { tanks }\end{array}$ & $\begin{array}{c}\text { Affected } \\
\text { area }\left(\mathbf{m}^{\mathbf{2}}\right)\end{array}$ & $\begin{array}{c}\text { Spill volume } \\
(\mathbf{L})\end{array}$ \\
\hline A & 6 & 120 & 3000 \\
\hline B & 4 & 100 & 2500 \\
\hline C & 6 & 120 & 3000 \\
\hline D & 4 & 80 & 2000 \\
\hline E & 7 & 140 & 3500 \\
\hline F & 4 & 80 & 2000 \\
\hline G & 5 & 100 & 2500 \\
\hline
\end{tabular}

Initially, concentration of dissolved BTEX in poral water system $\left(C_{i}\right)$ was estimated from Eq. (17). The percentage of each BTEX compound in different phases were calculated using Eqs. $10\left(C_{w}\right), 11\left(C_{a}\right), 12\left(C_{s}\right)$ and $13\left(C_{\text {NAPL }}\right)$ respectively.

Initial contaminant mass flux $\left(\mathrm{mg} / \mathrm{m}^{2} / \mathrm{y}\right)$ for each gas station was calculated based on Eq. (18). Furthermore, final contaminant flux in the recharge $\left(\mathrm{mg} / \mathrm{m}^{2} / \mathrm{y}\right)$ was calculated considering: (1) only sorption and volatilization processes (Eq. 22) and (2) sorption, volatilization and biodegradation processes (Eq. 25).

\section{RESULTS}

\section{Assessment of groundwater risk of contamination}

A hypothetical scenario was considered given the occurrence of a petroleum fuel leakage from the UHSS. Initial BTEX mass flux for each gas station is shown in Fig. 2 The greatest contaminant load was calculated for stations A, C and E (592, 553 and $550 \mathrm{mg} / \mathrm{m}^{2} /$ year respectively). For the rest of the sites (B, D, F and G) the initial mass flux was: 393, 248, $241 \mathrm{and} 352 \mathrm{mg} / \mathrm{m}^{2} / \mathrm{year}$ respectively. 
N

Initial mass flux

$\left(\mathrm{mg} / \mathrm{m}^{2} /\right.$ year $)$

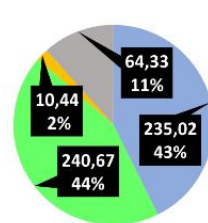

$\mathrm{E}=550$
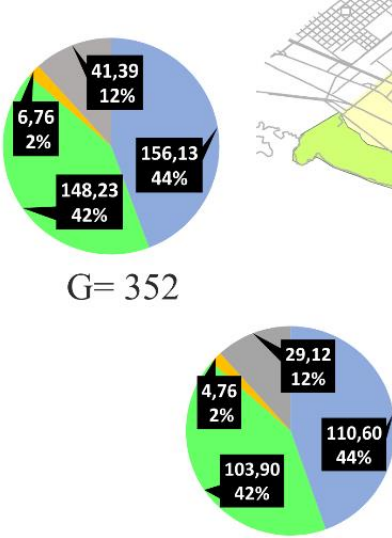

$\mathrm{D}=248$

$\mathrm{G}=352$
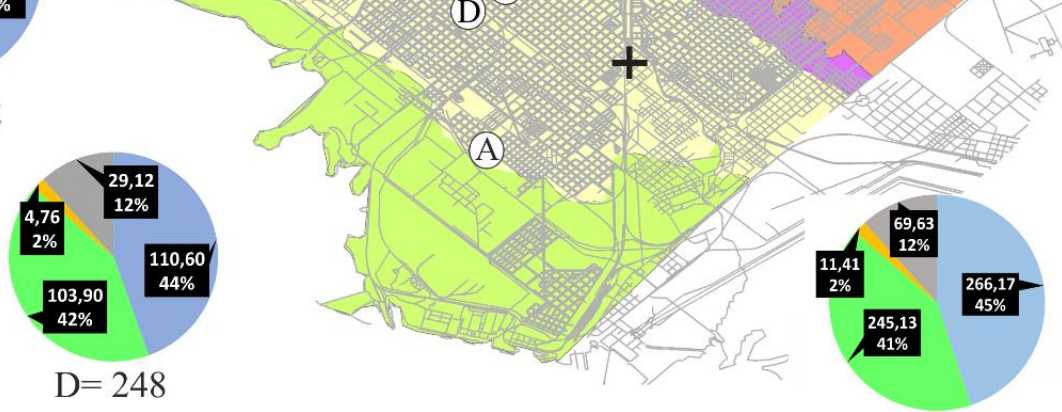

$\mathrm{A}=592$

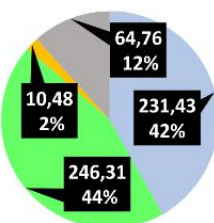

$\mathrm{C}=553$

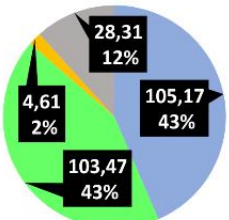

$\mathrm{F}=241$

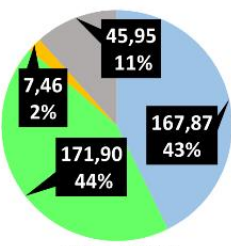

$\mathrm{B}=393$

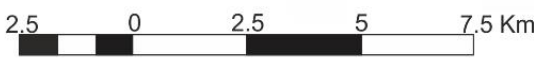

\begin{tabular}{|l}
$\square$ Benzene $\square$ Toluene \\
$\square$ Ethylbenzene $\square$ Xylene
\end{tabular}

Fig. 2 Map of initial mass flux

The final output of the model corresponds to a contaminant mass flux transported to groundwater. Two scenarios were evaluated: considering only sorption and volatilization processes (Fig. 3) and considering sorption and volatilization plus biodegradation (Fig. 4). The first scenario is represented by the retardation factor $(\mathrm{R})$ and the volatilization process. The inclusion of $\mathrm{R}$ in the transport equation (Eq. 20) increased the time necessary for BTEX to reached groundwater. Calculated R values for each gas stations are presented in table 5. In all cases it is observed that ethylbenzene has the highest $\mathrm{R}$ values followed by xylene, while toluene has the lowest ones. This behaviour is reflected in the velocity of contaminant, where the lower velocities are related to the higher $R$ values and vice versa. The sites where the velocity of contaminants is higher are A, D and G, the last two with very similar values between them.

Table 5 Calculated values of retardation index (R) and velocity of benzene (B), toluene (T), ethylbenzene (E) and xylene (X) for each gas station

\begin{tabular}{|c|c|c|c|c|c|c|c|c|}
\hline \multicolumn{4}{|c}{$\mathbf{R}$} & \multicolumn{4}{c|}{ Velocity of contaminant (m/d) } \\
\hline Gas stations & $\mathbf{B}$ & $\mathbf{T}$ & $\mathbf{E}$ & $\mathbf{X}$ & $\mathbf{B}$ & $\mathbf{T}$ & $\mathbf{E}$ & $\mathbf{X}$ \\
\hline A & 1.5 & 1.2 & 6.8 & 5.4 & $3.6 \mathrm{E}-04$ & $4.4 \mathrm{E}-04$ & $8.0 \mathrm{E}-05$ & $1.0 \mathrm{E}-04$ \\
\hline B & 9.0 & 4.1 & 103.7 & 78.5 & $8.5 \mathrm{E}-05$ & $1.9 \mathrm{E}-04$ & $7.4 \mathrm{E}-06$ & $9.7 \mathrm{E}-06$ \\
\hline C & 7.2 & 3.3 & 82.3 & 62.4 & $7.8 \mathrm{E}-05$ & $1.7 \mathrm{E}-04$ & $6.9 \mathrm{E}-06$ & $9.1 \mathrm{E}-06$ \\
\hline D & 2.8 & 1.8 & 23.3 & 17.8 & $1.6 \mathrm{E}-04$ & $2.5 \mathrm{E}-04$ & $1.9 \mathrm{E}-05$ & $2.5 \mathrm{E}-05$ \\
\hline E & 9.0 & 4.1 & 103.7 & 78.5 & $8.5 \mathrm{E}-05$ & $1.9 \mathrm{E}-04$ & $7.4 \mathrm{E}-06$ & $9.7 \mathrm{E}-06$ \\
\hline F & 5.0 & 2.6 & 52.8 & 40.1 & $8.9 \mathrm{E}-05$ & $1.7 \mathrm{E}-04$ & $8.5 \mathrm{E}-06$ & $1.1 \mathrm{E}-05$ \\
\hline G & 2.9 & 1.8 & 24.8 & 19.0 & $1.5 \mathrm{E}-04$ & $2.5 \mathrm{E}-04$ & $1.8 \mathrm{E}-05$ & $2.3 \mathrm{E}-05$ \\
\hline
\end{tabular}

The first scenario represented in the map is the most conservative one, only considering the occurrence of sorption and volatilization during transport (Fig. 3). In all cases, the compounds reach the water table in the following order toluene $>$ benzene $>$ xylene $\geq$ ethylbenzene. The site A exhibits the greatest final mass flux of contaminant (391 $\left.\mathrm{mg} / \mathrm{m}^{2} / \mathrm{year}\right)$. It is followed by gas 
station G with a final mass flux of $140 \mathrm{mg} / \mathrm{m}^{2} /$ year. Meanwhile, sites C, D, B and F have the lowest values, being 108, 99, 86 and $62 \mathrm{mg} / \mathrm{m}^{2} /$ year respectively.

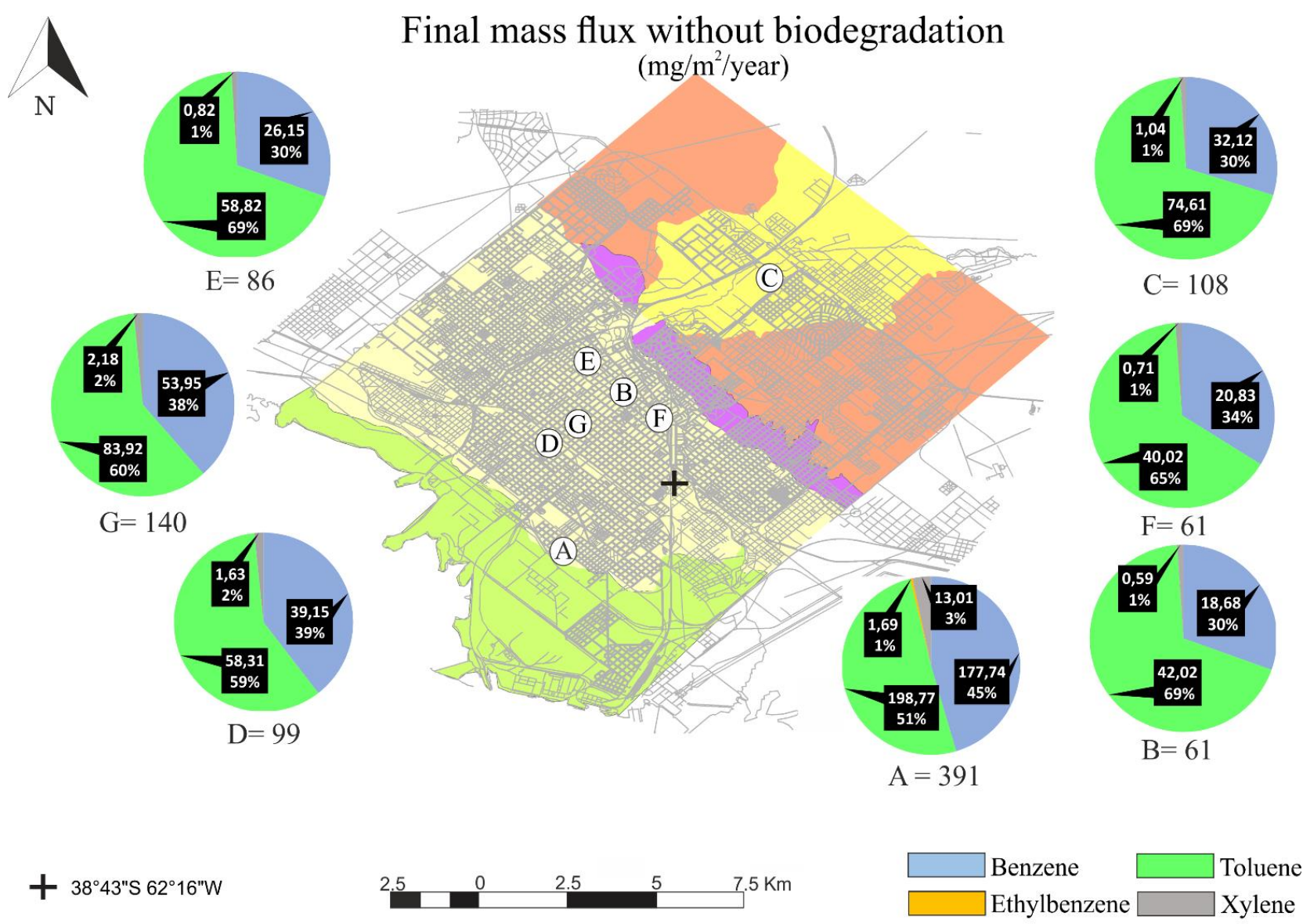

Fig. 3 Map of final mass flux considering only sorption and volatilization

In the second scenario, biodegradation effects generated an increase in the attenuation capacity of the UZ (Fig. 4). The final flux of pollutants to groundwater is significantly reduced for all sites. Location A is the only site whose values were higher than 50 $\mathrm{mg} / \mathrm{m}^{2} /$ year. Sites C and D have values of 0.70 and $0.40 \mathrm{mg} / \mathrm{m}^{2} /$ year respectively. While sites E, F, B and G do not register the presence of any BTEX. 


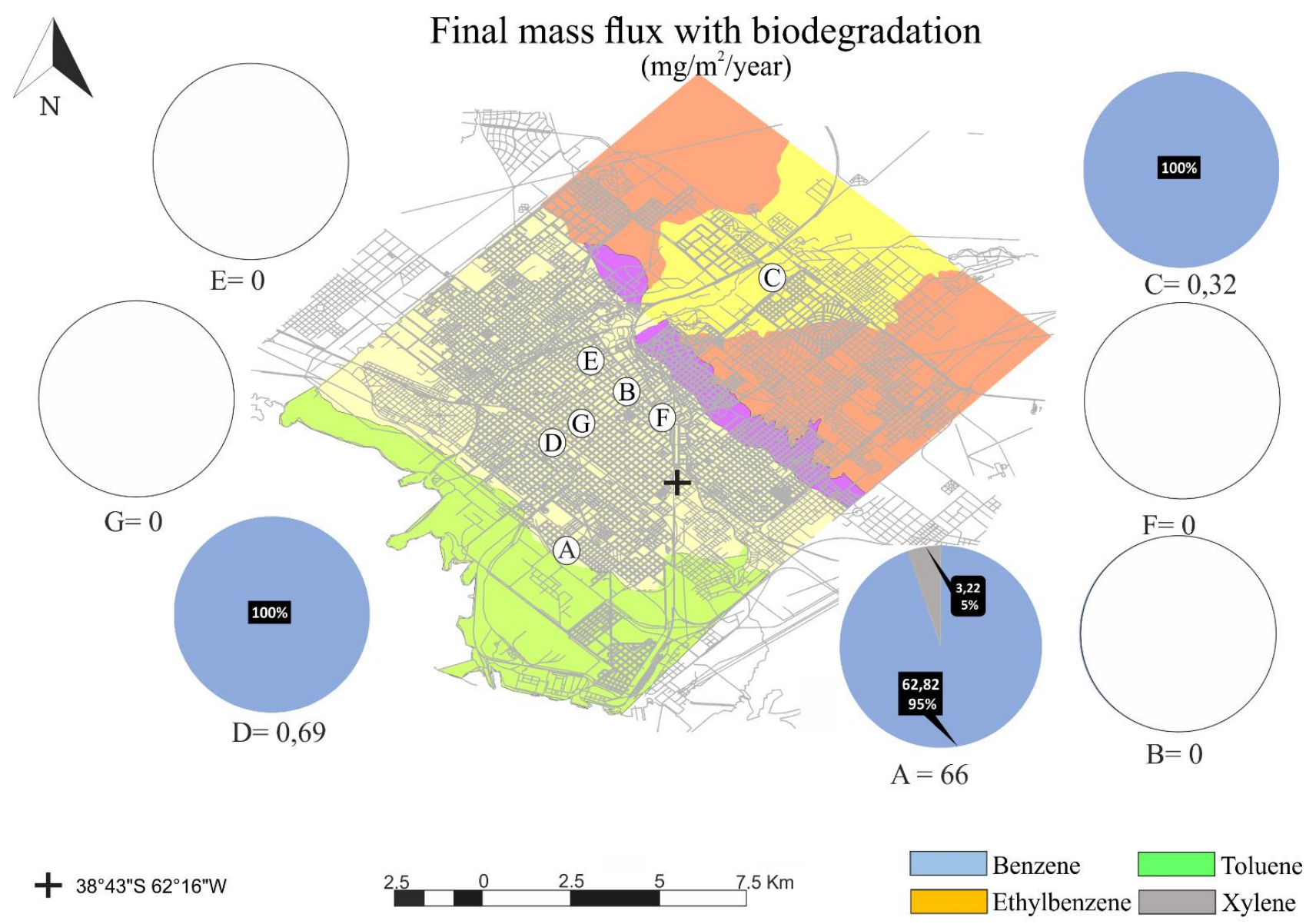

Fig. 4 Map of final mass flux considering sorption, volatilization and biodegradation

Most of the gas stations presented an expected behaviour, the higher the UZ thickness the lower the mass flux of contaminant. The best example is location A with the highest contaminant load reaching the aquifer. However, there are other cases that are not so straightforward, such as sites $\mathrm{G}$ and F. Location $\mathrm{G}$ has the deepest water table, nevertheless, a large amount of contaminant load reached the aquifer. Gas station F has one of the shallowest groundwater levels, but the contaminant load that reaches groundwater is low. This behaviour may be due to subsoil properties, which represent high R-index values. As explained above, the R-index refers to the attenuation capacity of the UZ.

\section{BTEX partitioning in different phases}

When a petroleum fuel leak occurs in the UZ, the compounds are distributed in different phases according to their partition constants and physical properties of the soil. Distribution of BTEX in NALP phase $\left(\mathrm{C}_{\mathrm{NALP}}\right)$, dissolved phase $\left(\mathrm{C}_{\mathrm{w}}\right)$, volatile phase $\left(C_{a}\right)$ and solid phase $\left(C_{s}\right)$ are illustrated in Fig. 5. Results are presented in two groups due to the different behaviours: Fig. 5a shows the results for gas station A, where storage tanks were arranged nearly above the water table; Fig. 5b represents the rest of the gas stations. In both situations all compounds are mainly concentrated in $\mathrm{C}_{\mathrm{NALP}}$, however some discrepancies in the BTEX distribution are present in the dissolved and solid phases, respectively. In Fig.5a benzene and toluene have the following order of preference $\mathrm{C}_{\mathrm{w}}>\mathrm{C}_{\mathrm{s}}>\mathrm{C}_{\mathrm{a}}$. Although ethylbenzene and xylene have the following order $\mathrm{C}_{\mathrm{s}}>\mathrm{C}_{\mathrm{w}}>\mathrm{C}_{\mathrm{a}}$. In Fig. 5b, benzene has the same way of partitioning as described previously. Toluene has a different distribution and the order of partitioning is $\mathrm{C}_{\mathrm{s}}>\mathrm{C}_{\mathrm{w}}$ $>C_{a}$. Despite ethylbenzene and xylene have the same behaviour than in Fig.5a, the concentration of $C_{w}$ is highly reduced. 


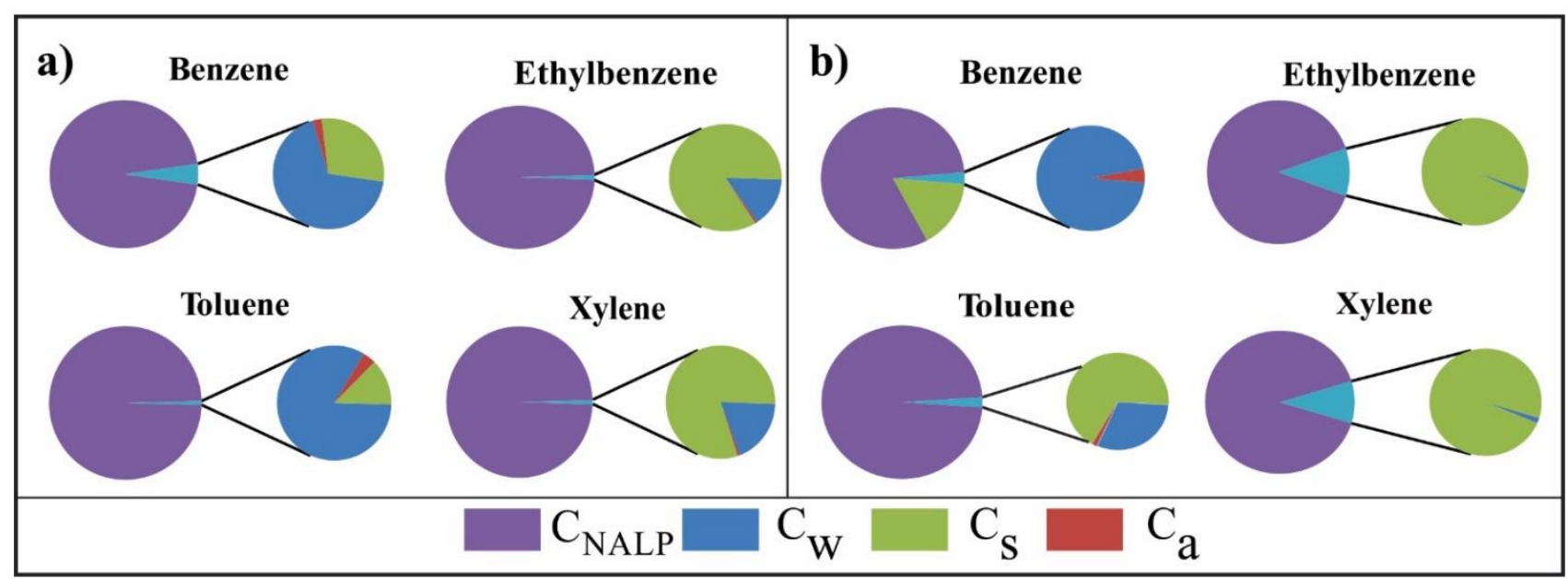

Fig. 5 a) Distribution of BTEX compounds in different phases in gas station A. b) Distribution of BTEX compounds in different phases in the rest of gas stations

The partitioning distribution of BTEX in dissolved, volatile and solid phase for each gas station is shown in Fig.6. Percentages of dissolved benzene, toluene, xylene and ethylbenzene are presented in Fig.6a. In the dissolved phase, for all locations, the mainly compound is benzene. Toluene has concentration in soil water two times lesser than benzene. Ethylbenzene and xylene have very low solubility. The highest percentages of benzene are present in sites A, C and G $(3.08,2.57$ and $2.65 \%$ respectively). Sites D and F have similar values (2.32 and $2.21 \%$ ) and sites B and E have the lowest (1.66 \% both locations).

BTEX distribution in the volatile phase is similar to the dissolved phase (Fig.6b). In all cases, the compound that easily volatilizes is benzene. Toluene volatilizes three times lesser than benzene and ethylbenzene, and xylene concentration in the gaseous phase are negligible. The highest volatilization percentages of benzene are observed in gas station B and E ( $0.35 \%)$. Otherwise, locations D, F and G present values of $0.27 \%, 0.26 \%$ and $0.19 \%$ respectively. Finally, sites A and C have the lowest percentages $(0.11 \%)$.

Percentages of sorbed compounds in soil are illustrated in Fig.6c. The behaviour of BTEX in the solid phase is different than the dissolved and volatile phases. Although benzene continues to be the predominant compound in all locations, it is followed by ethylbenzene and xylene. Toluene concentrations in solid phase are very low with a maximum value of $1.42 \%$ and a minimum of $0.01 \%$. The highest values of sorbed components are observed in gas stations C, B, E and F. Sites B and E have the same behaviour, so it was considering like the same in the description. Values of benzene are: $15.77 \%$ in gas station $\mathrm{C}, 12.82 \%$ (sites $\mathrm{B}$ and E) and $8.60 \%$ in gas station F. Values of ethylbenzene and xylene are very similar $10.58 \%$ in C, $8.43 \%$ (B and E) and $5.59 \%$ in F. Gas stations $\mathrm{G}$ and $\mathrm{D}$ have lower values than the recently mention, but the order of the compounds is the same. The presence of benzene is $4.74 \%$ and $3.88 \%$ respectively, ethylbenzene and xylene $3.04 \%, 2.47 \%$ and $2.65 \%, 2.16 \%$ and toluene negligible. Finally, location A has values lesser than $1 \%$ for all compounds. 


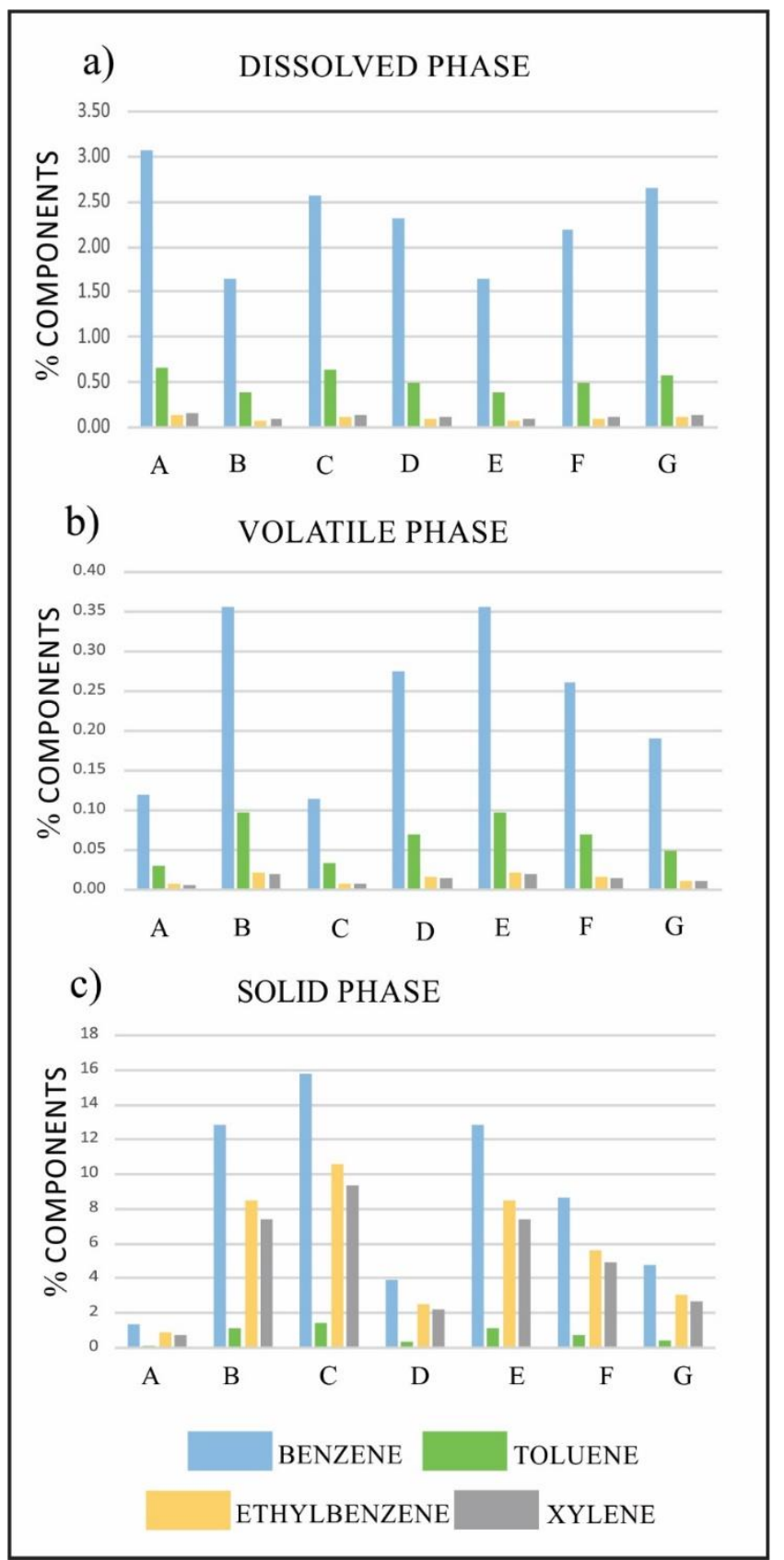

Fig. 6 Behaviour of BTEX components in each gas station for phases: a) dissolved b) volatile and c) solid

\section{DISCUSSION}

The application of the theoretical model proposed by Thomas and Tellam (2004) in our study area showed good results. Accordantly, it was possible to establish the distribution of BTEX in the subsystems of UZ (dissolved, solid and volatile phase) and the pollutant load leached into the aquifer for several gas stations locations.

Gas stations A, C and E have the highest number of tanks installed, for this reason they have the greatest initial contaminant load. Analysing the final mass flux that reaches the aquifer considering only sorption and volatilization processes, the locations with the highest load are $\mathrm{A}>\mathrm{G}>\mathrm{C}>\mathrm{D}>\mathrm{E}>\mathrm{B}>\mathrm{F}$. Nevertheless, considering biodegradation process, concentrations of contaminants reaching the aquifer drastically decrease and, in some locations, it becomes null. Only gas station A continues with high values of contaminant load, followed by station C and D with lower values. Most BTEX are degraded in the UZ before they even reach the water table. Differences in the amount of contaminant reaching the aquifer may be related to the depth of the water table and the different velocities of the compounds depending on the lithology involved. The mobility of BTEX compounds is closely related to the physico-chemical characteristics and subsoil properties of each site. (Zanello et al. 2021).

The partitioning of each BTEX compound in UZ was analysed considering NALP, dissolved, solid and volatile phases. As expected, BTEX was mainly concentrated in the NALP phase (between 81 and 98\%). However, if this phase is not considered, the compounds were concentrated in the solid phase in the following order: benzene>ethylbenzene>xylene>toluene. Thomas 
and Tellam (2004) informed a similar behaviour of BTEX compounds in their work. Van der Zon (2012) also suggests that without water table fluctuation BTEX compounds remain in the UZ. An exception was gas station A because a leak from its UHSS leaked directly into the water table. Throughout the work, when water table was less than 2 metres deep, the compounds partitioned as follows $C_{w}>C_{s}>C_{a}$ for benzene and toluene, and $C_{s}>C_{w}>C_{a}$ for ethylbenzene and xylene. Compounds with higher solubility start to dissolve when NAPL is almost above the water table. Benzene and toluene are the most water-soluble compounds. Otherwise, ethylbenzene and xylenes are mainly concentrated in the solid phase, given their affinity for organic particles and their high octanol-water partition value $\left(\mathrm{K}_{\mathrm{oh}}\right)$. Nevertheless, if the UZ is thick (more than 2 meters), all the compounds partitioned as $\mathrm{C}_{\mathrm{s}}>\mathrm{C}_{\mathrm{w}}>\mathrm{C}_{\mathrm{a}}$. As the thickness of the UZ increases, the moisture content in the soil decreases, making the solubility of the compounds more difficult. While migrating through the soil, the compounds are retained by solid particles. Therefore, there is a delay in transit time during their transport to groundwater. In agreement with Park and Juan (2000), as leachate moves through the soil, contaminant concentrations are attenuated by adsorption and biodegradation. The low proportions of all BTEX compounds in the volatile phase may be related to low values for Henry's constants.

Although gas stations A, C and D have the shallowest water table, site G also has high percentages of dissolved compounds. This could be related to the subsoil texture or the amount of organic matter present in the subsoil. Loamy sand is characterised by a higher moisture retention content, thus increasing effective permeability of the soil. In other areas of the city, the water table is similar to the depth of site G, but UZ is composed of coarse grain sizes (predominantly sand) with lower average moisture content. This work accepts an approach that contaminants will only be absorbed by organic matter. Although this affinity is very strong, there are other soil components, such as clays or oxides, which will interact with petroleum fuels. This interaction could also modify the contaminants mass of the system in transfer processes (Balseiro-Romero et al. 2018).

The model allows us to calculate the mass flux of contaminants leached to groundwater in the case of a hypothetically pollutant event and helps to predict which areas from Bahía Blanca city are more vulnerable to contamination. In particular, the tidal plain is the geomorphological zone that presents the greatest danger for soil and groundwater contamination due to the proximity of the water table to the surface. For the other geomorphological zones (plateau, colluvial-alluvial and river valley) studies need to be more detailed, owing to physical conditions within the same geomorphological zone can vary widely.

The presented model can delimit risk zones of contamination in urban areas. Consequently, it can be used as a first instance in a remediation plan, or for urban environments sustainability. It should be noted that if more field data is supplied to the model, more accurate will be the results. The theoretical model can be adapted to other cities, being a powerful tool for decisions makers agencies in environmental assessment according to site-specific conditions.

\section{CONCLUSIONS}

- The proposed theoretical model proved to be useful for the study area, allowing to know the behaviour of a possible hydrocarbon contamination from the UHSS of the gas stations linking it to the different geomorphological zones of Bahía Blanca.

- The partitioning of the BTEX compound in UZ was analysed considering the NALP, dissolved, solid and volatile phases. As expected, BTEX compounds was mainly concentrated in the NALP phase (between 81 and $98 \%$ ). Hypothetically, if NALP is not present, the compounds preferred the solid phase (when UZ thicknesses are greater than 2 meters) or the dissolved phase (when UZ thicknesses are less than 2 meters). In this work, the volatile phase is negligible for all compounds.

- For this study, the compounds are most readily absorbed in the following order benzene>ethylbenzene>xylene>toluene and dissolved in the following order benzene>toluene>xylene>ethylbenzene.

- Soil texture directly influences soil moisture content, as well as soil permeability, giving it different properties for the transport of monoaromatic contaminants in the subsoil.

- Particularly, the tidal plain is the geomorphological zone that presents a greater danger for soil and groundwater contamination due to the proximity of water table to the surface. For the other geomorphological zones (plateau, colluvial-alluvial and river valley) the studies must be more detailed. This is because the physical conditions within the same geomorphological zone can widely vary.

- In general, sorption and biodegradation processes generate an attenuation effect. Biodegradation plays a fundamental role as an attenuator for this monoaromatic contaminants. However, extensive studies are required to ensure the existence of degradation bacteria in the unsaturated media.

\section{REFERENCES}

Atteia O, Guillot C (2007) Factors controlling BTEX and chlorinated solvents plume length under natural attenuation conditions. J Contam Hydrol 90(1-2):81-104. https://doi.org/10.1016/j.jconhyd.2006.09.012

Balseiro-Romero M, Monterroso C, Casares JJ (2018) Environmental Fate of Petroleum Hydrocarbons in Soil: Review of Multiphase Transport, Mass Transfer, and Natural Attenuation Processes. Pedosphere 28(6):833-847. https://doi.org/10.1016/S1002-0160(18)60046-3

Bonorino AG, Sala JM (1983) Capitulo: Geohidrología. Comisión Estudio de Suelos White-Cerri. MOP de la Provincia de Buenos Aires. Informe Final. La Plata. Inédito. 
Caló J, Fernández E, Marcos A, Aldacour H (1999) Construcción de mapas geológico ingenieriles a partir de conocimientos previos compilados en un sistema de información geográfica. Rev de Geol Apli a la Ing y al Amb 13:1-10.

Caló J, Fernández E, Marcos A, Sequeira M (2004) Medidas de mitigación de los impactos Ambientales producidos por lluvias intensas en la ciudad de bahía blanca. VIII Simposio de Geología Aplicada a la Ingeniería y al Medioambiente. Córdoba, Argentina.

Carrica JC, Lexow C (2006) Subsidencia en el área costera de Bahía Blanca, Argentina. VIII Congreso Latinoamericano de Hidrología Subterránea. Asunción, Paraguay (En CD).

Celis Huaiquilaf B (2009) Contaminación de aguas subterráneas por hidrocarburos líquidos livianos en fase no acuosa. Ciencia Ahora 22:20-29.

Charbeneau RJ, Daniel DE (1992) Contaminant transport in unsaturated flow. In: Maidment DR (ed) Handbook of Hydrology, Cap 15. McGraw Hill, New York, pp 15-54.

Cipullo S, Prpich G, Campo P, Coulon F (2018) Assessing bio- availability of complex chemical mixtures in contaminated soils: Progress made and research needs. Sci Total Environ 615:708-723. https://doi.org/10.1016/j.scitotenv.2017.09.321

Clapp RB, Hornberger GM (1978) Empirical Equations for Some Soil Hydraulic Properties. Water Res Res 14(4):601-604.

Cline PV, Delfino JJ, Rao P, Suresh C (1991) Partitioning of aromatic constituents into water from gasoline and other complex solvent mixtures. Env Sci \& Tech 25(5):914-920. https://doi.org/10.1021/es00017a013

Derrick ON, Stephen AA, Peter CU (2005) The dissolution rate of BTEX components in water. Canadian J Chem Eng 83:985989.

Feenstra S, Mackay DM, Cherry JA (1991) Presence of residual NAPL based on organic chemical concentrations in soil samples. Ground Water Monit Rev II (2):128-136. https://doi.org/10.1111/j.1745-6592.1991.tb00374.x

Fetter CW, Boving TB, Kreamer DK (1999) Contaminant hydrogeology. Prentice Hall, Upper Saddle River, NJ.

Freeze RA, Cherry JA (1979) Groundwater. Prentice-Hall, Englewood Cliffs, New Jersey.

Gustafson JB, Tell JG, Orem D (1997) Selection of representative TPH fractions based on fate and transport considerations. Amherst Scientific Publishers, Amherst, Massachusetts.

Kim J, Corapcioglu MY (2003) Modeling dissolution and volatilization of LNAPL sources migrating on the groundwater table. J Contam Hydrol 65(1-2): 137-158. https://doi.org/10.1016/S0169-7722(02)00105-5

Lexow C (1994). Las estaciones de servicio como fuente de contaminación del agua subterránea. Rev. Del Museo de Ciencias $3(2): 5-8$.

Mercer JW, Cohen RM (1990) A review of immiscible fluids in the subsurface: Properties, models, characterization and remediation. J Contam Hydrol 6(2):107-163. https://doi.org/10.1016/0169-7722(90)90043-G

Njobuenwu DO, Amadi SA, Ukpaka PC (2008) Dissolution rate of BTEX contaminants in water. The Canadian J Chem Eng 83(6):985-989. https://doi.org/10.1002/cjce.5450830608

Park HS, Juan CS (2000) A method for assessing leaching potential for petroleum hydrocarbons release sites: Multiphase and multisubstance equilibrium partitioning. Soil Sediment Contam 9(6):611-632. https://doi.org/10.1080/10588330091134437

Pérez Marfil P, Scherger L, Priano C, Lescano L, Pera Vallejos G, Lafont D, Lexow C, Marfil S (2019) Pavimentos de hormigón de la ciudad de Bahía Blanca. Relación del grado de deterioro con el comportamiento hidrodinámico de la zona no saturada. Rev de Geol Apli a la Ing y al Amb 43:27-37.

Rodrigo Ilarri J, Romero Ballesteros L, Rodrigo Clavero ME (2018) Modelación matemática de la concentración de BTEX en la zona no saturada: evaluación de la distribución de masa entre las fases. Agua subterránea, medio ambiente, salud y patrimonio. Congreso Ibérico, Salamanca, 497-506.

Sanders L (1998) A manual of field hydrogeology. Prentice-Hall, Englewood Cliffs, New Jersey.

Silva MAB (2005) Sistema de classificação fuzzy para áreas contaminadas, Tese (Doutorado em Ciências em Engenharia Civil) Universidade Federal do Rio de Janeiro. 
Thomas A, Tellam J (2004) Development of a GIS model for assessing groundwater pollution from small scale petrol spills. In: Howard KWF (ed) Chapter 9 in: Urban Groundwater-Meeting the Callenge, London, UK, pp 107-127.

Valsala R, Govindarajan SK (2018) Interaction of dissolution, sorption and biodegradation on transport of BTEX in a saturated groundwater system: Numerical modeling and spatial moment analysis. J Earth Syst Sci 127(4):53. https://doi.org/10.1007/s12040-018-0950-3

Van Der Zon PWF (2012) Modeling the behavior of ethanol and BTEX in groundwater contaminated with ethanol-85. Tesis de Maestría, Utrecht University.

World Health Organization (WHO) (1996) Guidelines for drinking-water quality, Health criteria and other supporting information. World Health Organization (2do edn), Geneva.

Zanello V, Scherger LE, Lexow C (2021) Assessment of groundwater contamination risk by BTEX from residual fuel soil phase. SN Applied Sciences 3(3):307-327. https://doi.org/10.1007/s42452-021-04325-w 
Figures

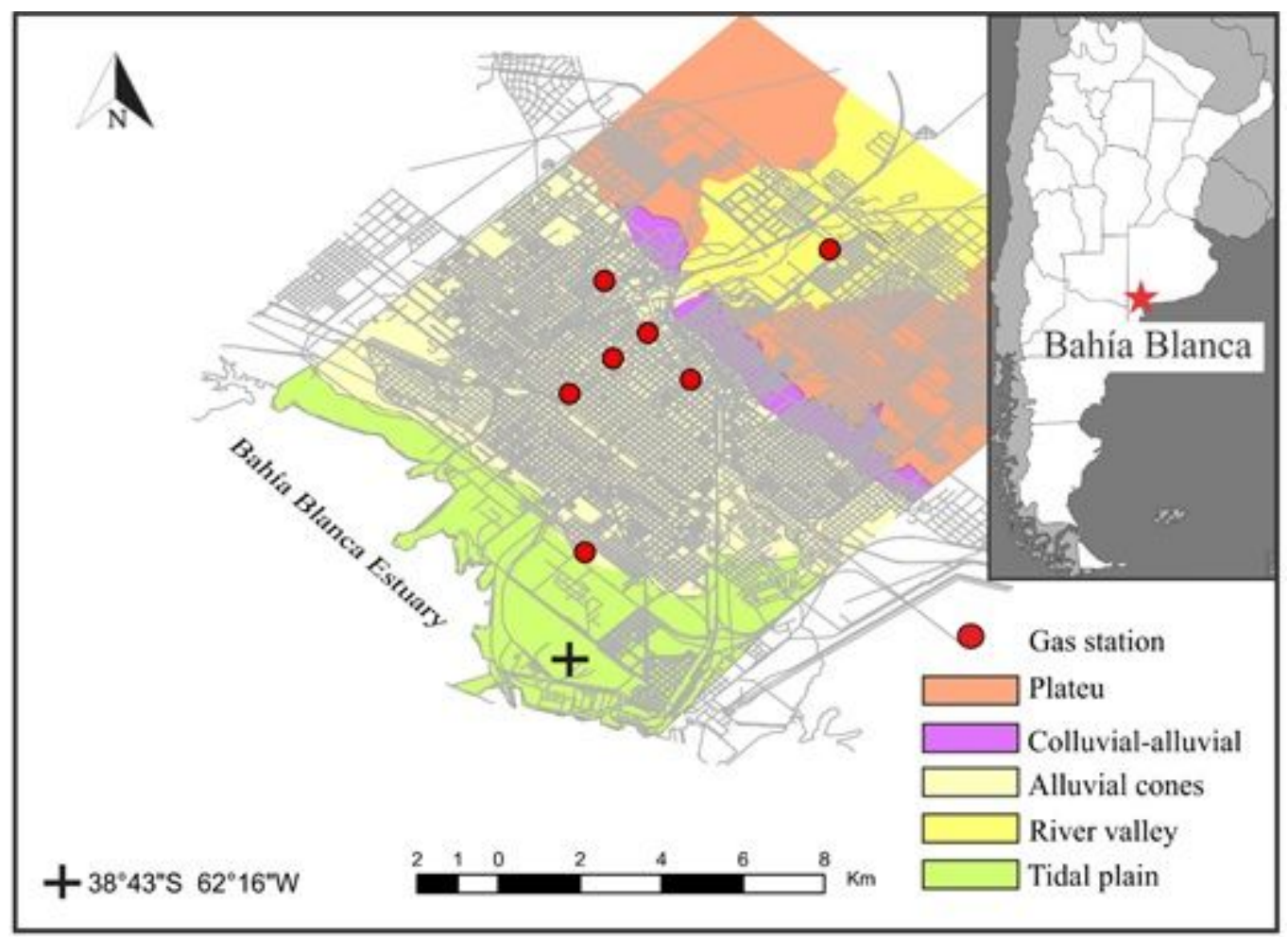

\section{Figure 1}

Map of the geomorphologic units of Bahía Blanca city (Modify from Pérez Marfil et al. 2019) 
“雷曷

$\mathrm{E}=550$
Initial mass flux

( $\mathrm{mg} / \mathrm{m}^{2} /$ year)

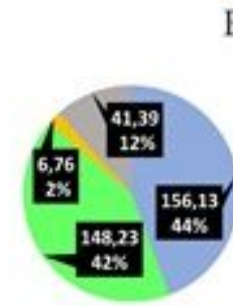

$\mathrm{G}=352$

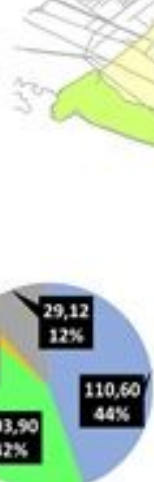

$\mathrm{D}=248$

$+38^{\circ} 43^{\circ} \mathrm{S} 62^{\circ} 16^{\circ} \mathrm{W}$
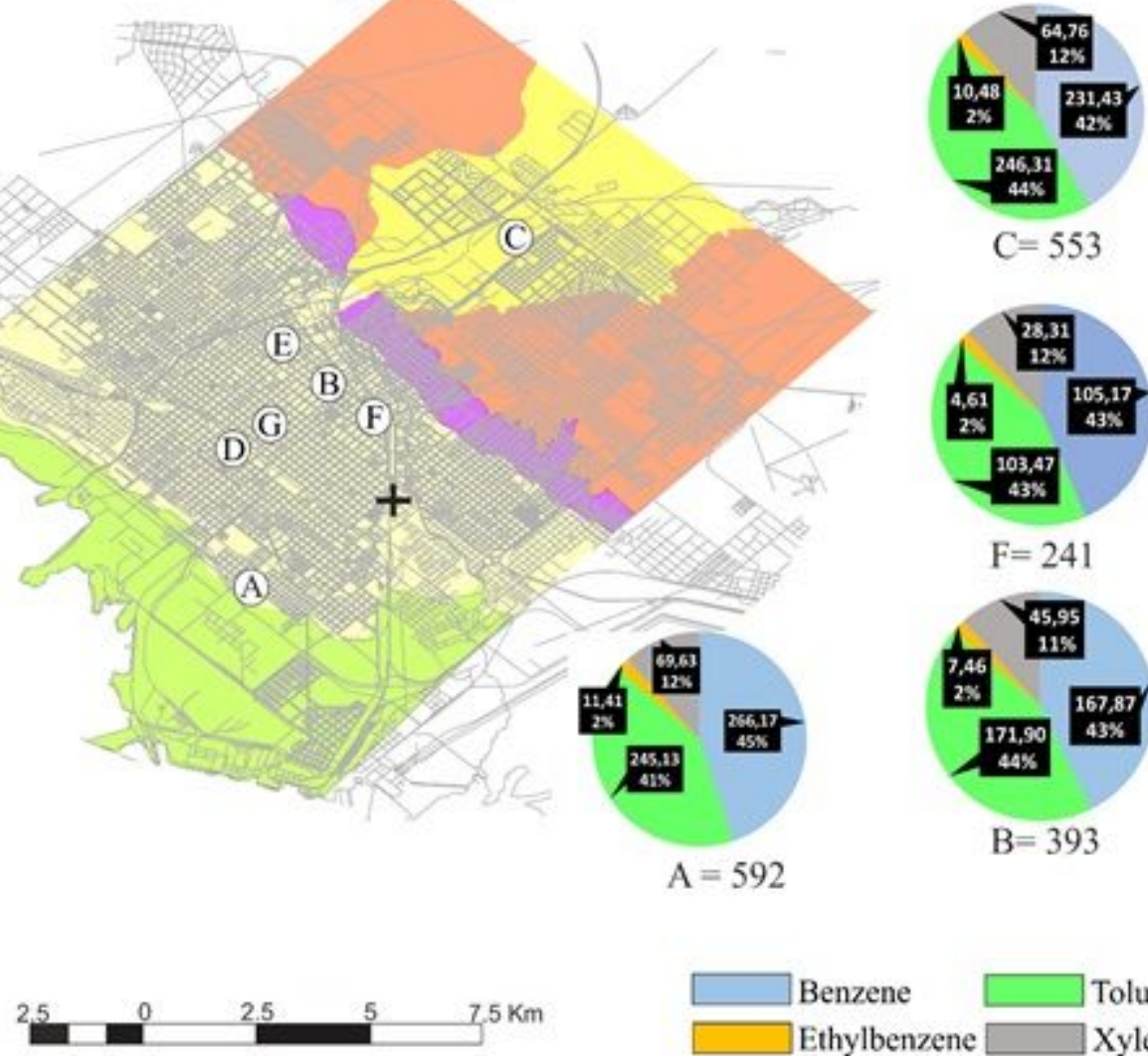

$\mathrm{C}=553$

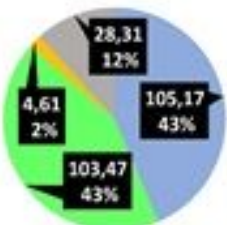

$$
F=241
$$

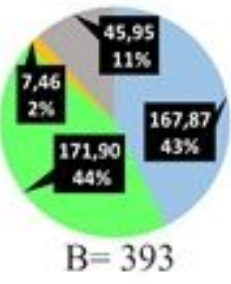

Figure 2

Map of initial mass flux 


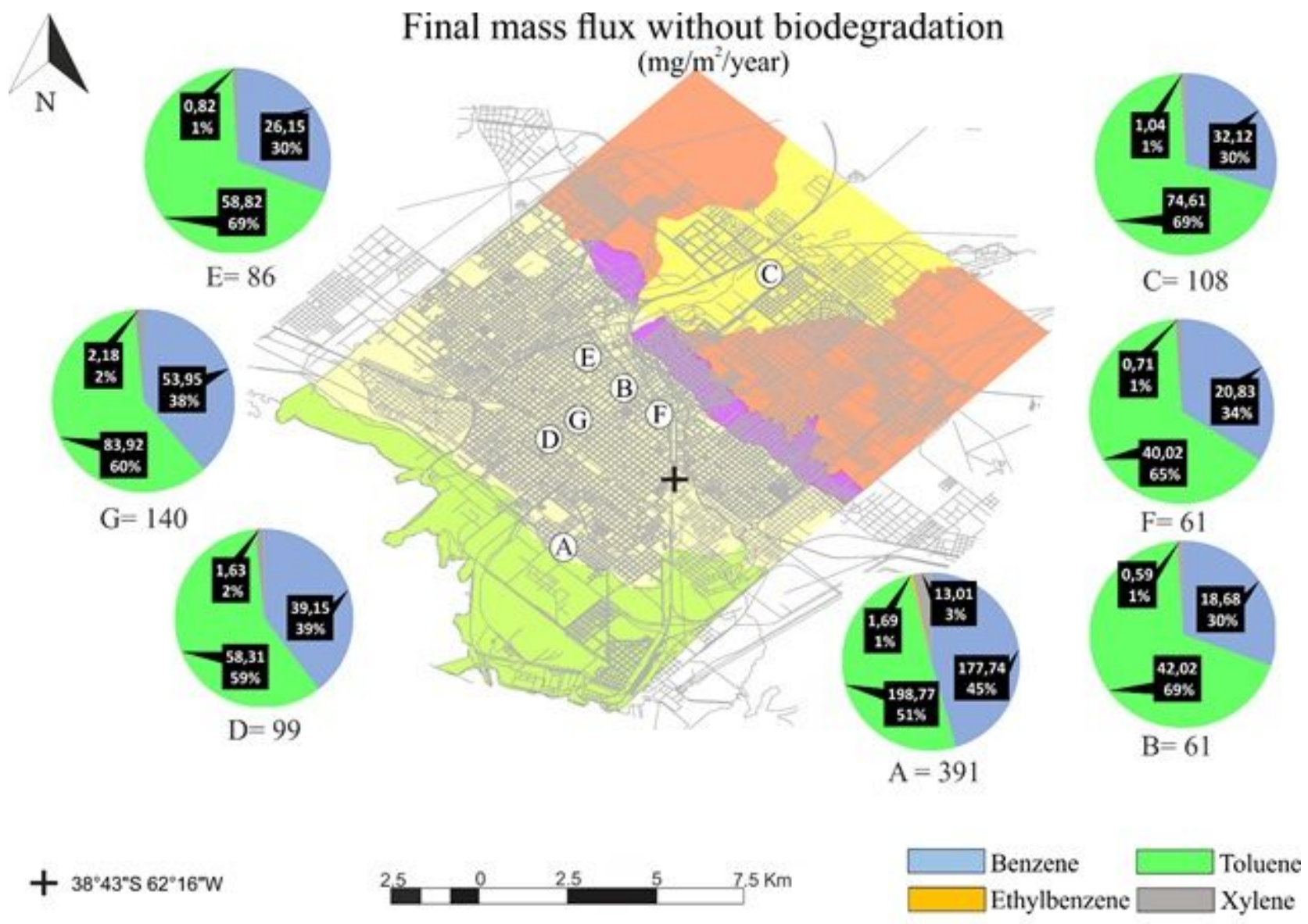

Figure 3

Map of final mass flux considering only sorption and volatilization 
Final mass flux with biodegradation

$\mathrm{N}$

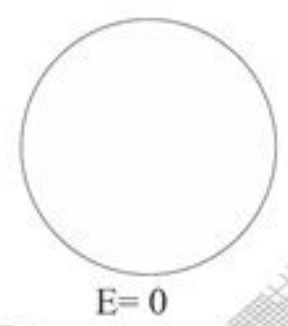

$\left(\mathrm{mg} / \mathrm{m}^{2} /\right.$ year)
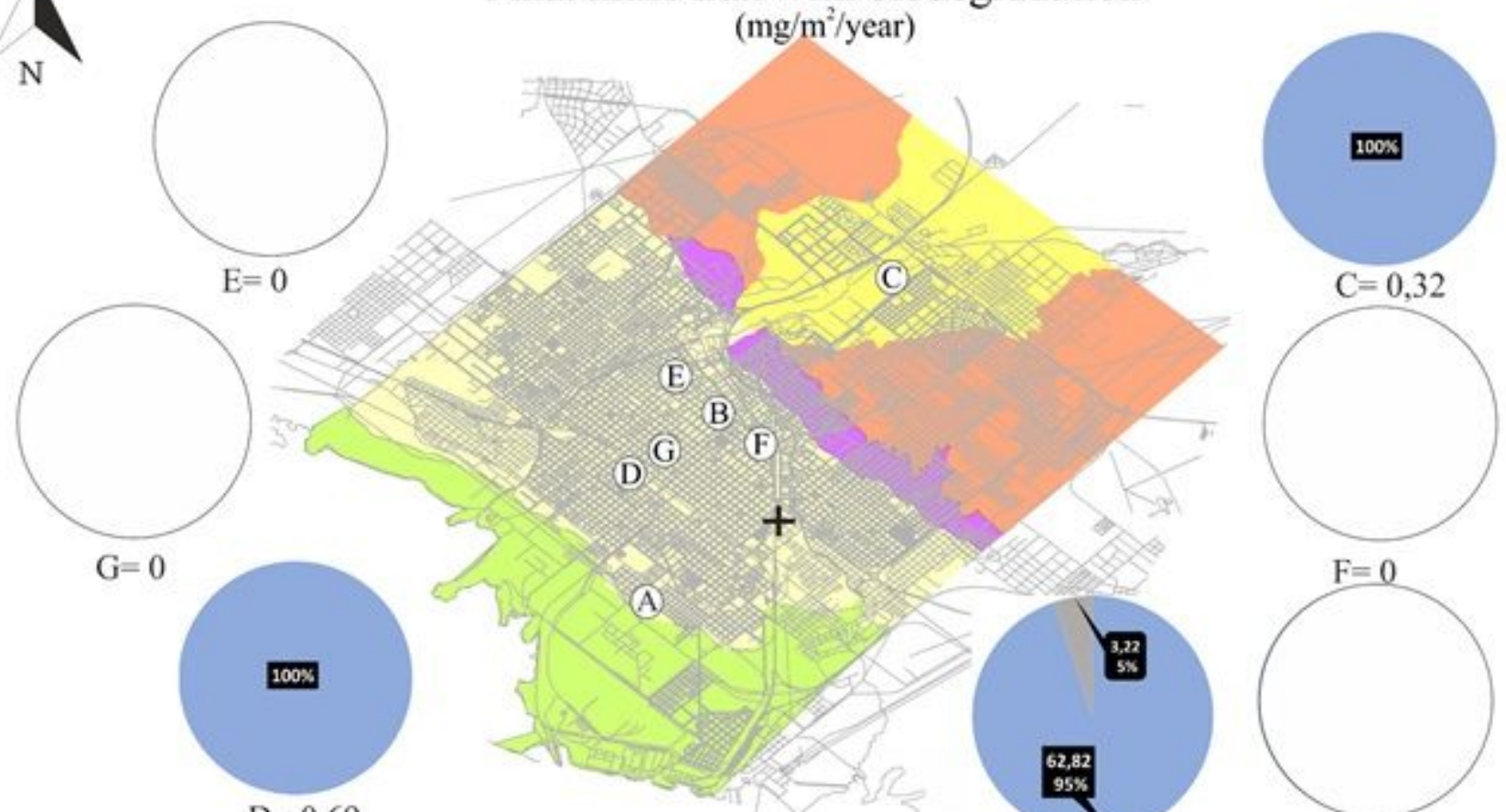

$\mathrm{D}=0,69$

E

B

D

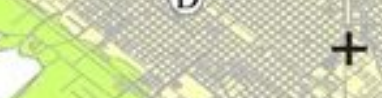
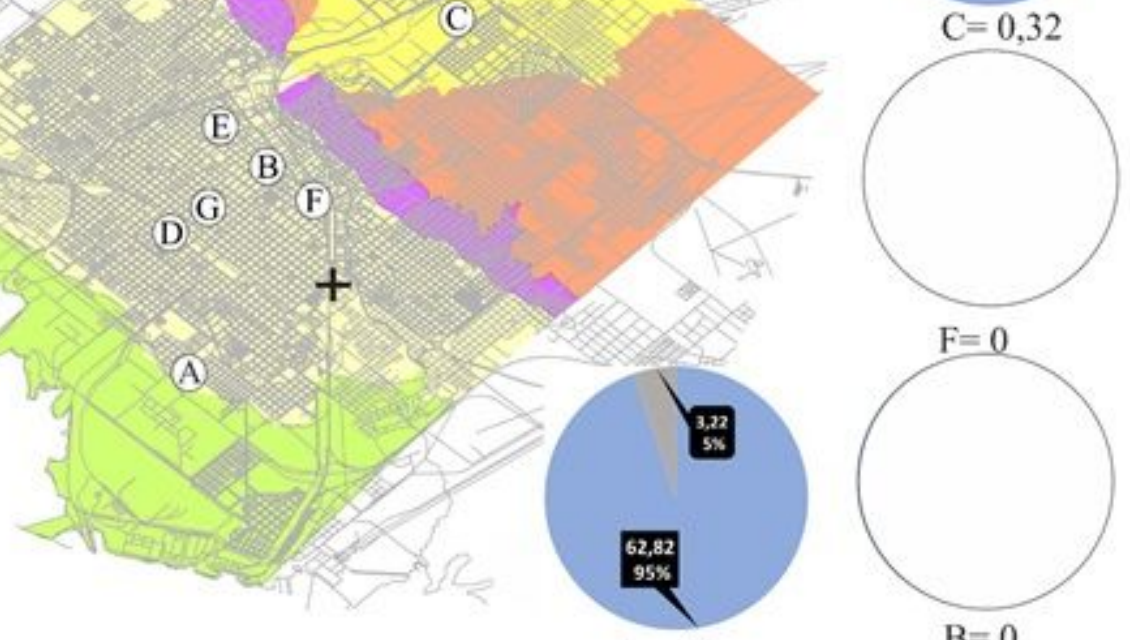

$\mathrm{A}=66$

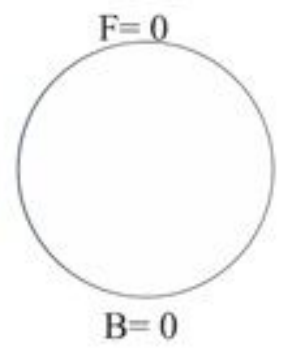

$+38^{\circ} 43^{\circ} \mathrm{S} 62^{\circ} 16^{\circ} \mathrm{W}$
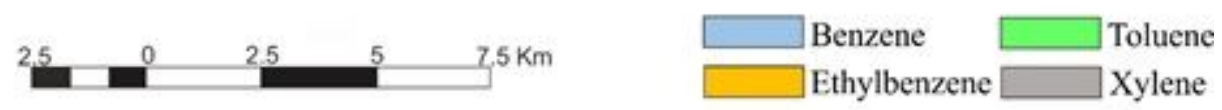

\section{Figure 4}

Map of final mass flux considering sorption, volatilization and biodegradation

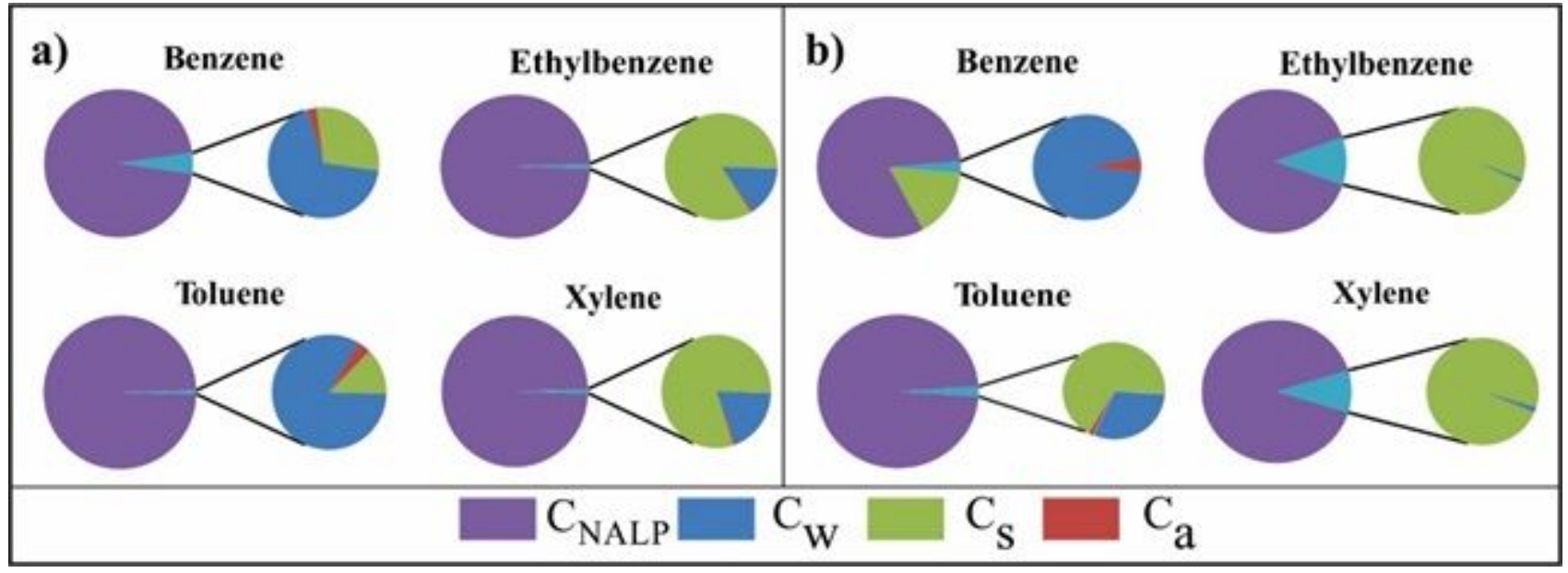

\section{Figure 5}

a) Distribution of BTEX compounds in different phases in gas station A. b) Distribution of BTEX compounds in different phases in the rest of gas stations 


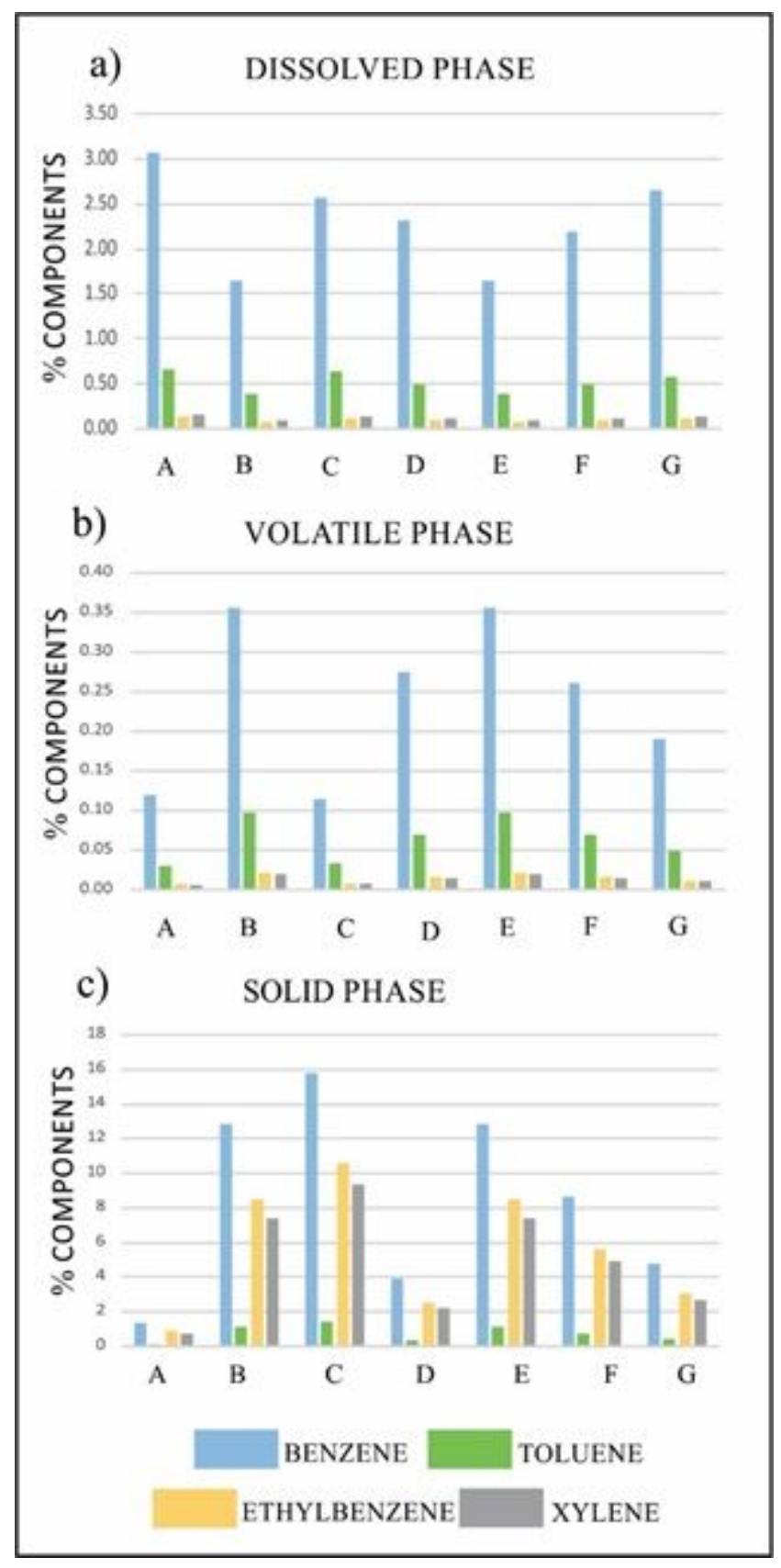

Figure 6

Behaviour of BTEX components in each gas station for phases: a) dissolved b) volatile and c) solid 